\title{
1 Food-borne mycotoxin hazards in the Kenyan market-a retrospective study
}

2 James Karuku Kibugu ${ }^{1,2 *}$, David Mburu ${ }^{2 \mp,}$ Leonard Karongo Munga ${ }^{2 \uparrow,}$, Richard Kurgat ${ }^{1}$,

3 Bernard Mukasa ${ }^{1}$, Fransisca Naliaka Lusweti ${ }^{1}$, Delia Grace ${ }^{3}$, Johanna Lindahl ${ }^{3}, 4,5$

4

5

6

7

8

${ }^{1}$ Kenya Agricultural and Livestock Research Organization, Nairobi, Kenya

2 Kenyatta University, Nairobi, Kenya

${ }^{3}$ International Livestock Research Institute, Nairobi, Kenya

${ }^{4}$ Swedish University of Agricultural Sciences, Uppsala, Sweden

${ }^{5}$ Uppsala University, Uppsala, Sweden

* Corresponding author

E-mail: jkkibugu1@yahoo.com (JKK)

TThese authors contributed equally to this work

\section{Abstract}

Mycotoxin contamination data $(n=1818)$ in feed and food from major laboratories were categorized into hazardous and non-hazardous using contaminants regulatory limits, analyzed by logistic regression and chi-square test to identify potential health hazards. Feeds were most contaminated, with $64 \%$ and $39 \%$ having total aflatoxin (AFT) levels above Kenyan and American standards respectively. Peanuts, the most contaminated food, had $61 \%$ and $47 \%$ of samples failing Kenyan and American AFT standards respectively. By European standards, wheat had highest AFT contamination rate of $84 \%$. Half of baby foods sampled had AFT level above Kenyan and European standards. Maize had failure rates of 20\% (Kenyan standard), 14\% (American standard) and 25\% (European standard) for AFT. We observed high frequency of mycotoxins (AFT, aflatoxin M1, zearalenone, T-2 toxin, ochratoxin A, fumonisins, deoxynivalenol) and AFT hazards with significantly $(p<0.001)$ higher failure rates in wheat, peanuts, mycotoxin hazards in dairy products in that order (European standard). Failure rates were significantly $(p<0.001)$ higher in feed ingredients $(p<0.01)$, baby foods $(p<0.05)$, maize $(p<0.001)$, fodder $(p<0.05)$ for mycotoxins, and compound feeds, peanuts, wheat $(p<0.001)$, feed ingredients, baby foods $(p<0.01)$, maize $(p<0.001)$, fodder $(0.01)$, in that order, for AFT (American standard). Fail rates were significantly higher for mycotoxins in compound feeds, feed ingredients, peanuts, wheat, baby foods, maize $(p<0.001)$, herbal health drink $(p<0.01)$, and for AFT in compound feeds, feed ingredients, peanuts, wheat $(p<0.001)$, baby foods $(p<0.01)$, herbal health drink $(p<0.05)$, maize $(p<0.001)$ in that order (Kenyan standard). High frequency of mycotoxin and AFT hazards in maize, baby foods, herbal health drink and aflatoxin M1 in dairy products was noted. Detection by different laboratories varied significantly $(p<0.001)$. Health and economic implications of this and limitations of current food safety standards are discussed. Humans and animals in Kenya are chronically exposed to mycotoxin hazards that require constant surveillance and strict regulation. 


\section{Introduction}

Mycotoxins are toxic secondary metabolites produced by toxigenic fungi that infest food and feed materials during pre- and post-harvest periods [1]. The most commonly encountered dietary mycotoxins with worldwide occurrence are aflatoxins, ochratoxins, zearalenone, fumonisins, trichothecenes and patulin produced by the fungal genera Aspergillus, Penicillium and Fusarium $[1,2,3,4]$. Children in Africa are continuously exposed to dietary mycotoxins [5]. Effects of chronic exposure include aggravation of disease pathogenesis in experimental animals and humans $([6,7,8]$, reduced animal productivity [9], and impaired animal nutrition [10]. Mycotoxins can also be teratogenic, carcinogenic, mutagenic, estrogenic, nephrotoxic, hepatotoxic and immunosuppressive in humans and animals $[4,8]$. Aflatoxin is an important risk factor for primary hepatocellular carcinoma, and is also associated with childhood stunting and immune depression in humans $[11,12,13,14]$. There is widespread distribution of aflatoxigenic fungi in Kenya [3], and where indeed acute aflatoxicosis in human and animals resulting in deaths has occurred $[15,16,17]$. Other than threatening human and animal health, mycotoxins also affect international trading and contribute to food and feed insecurity [1]. Most mycotoxins are stable to normal cooking and processing. After consumption, some mycotoxin metabolites can be carried over in utero [18], in breast milk $[9,19,20]$ and in animal products [13]; all contribute to mycotoxin exposure in humans.

In order to protect humans from exposure, Kenya as well as many other countries have regulatory limits for some mycotoxins $[1,2,21,22]$. However, standards are rarely enforced in the developing world [23]. There are commercial and government laboratories that offer quality assurance services for food material destined for export and local consumption. The purpose of this study was to review available data from testing laboratories in order to 
identify potential dietary mycotoxin hazards in Kenya, and estimate their frequency as health risk factors.

\section{Materials and methods}

69

\section{Data collection and management}

We developed a list of major mycotoxin-testing laboratories in Kenya [15] as a sampling frame, and collected data on total aflatoxin (AFT), aflatoxin M1 (AFM1), zearalenone (ZEA), T-2 toxin, ochratoxin A (OTA), total fumonisins (FUMS) and deoxynivalenol (DON) contamination in human foods and animal feeds from the laboratories (Lab1, Lab2 and Lab3). One of the laboratory was a public institution that deals with agricultural research while the other two were private laboratories (Lab2 and Lab3) that process samples for clients.

Results of 1818 samples (323 and 1495 samples of animal feeds and human food respectively) analysed for mycotoxin residue levels between 2010 and 2015 were acquired for further analysis. The data were first broadly grouped into animal feeds and human foods and then further categorized into compound feeds, feed ingredients, and fodder feeds for animal feeds, and baby foods, herbal health drink, maize, peanuts, dairy products, tea, wheat, on-the-plate (maize slurry, omena, vegetables) and other foods for humans. When the results were below the limit of detection, we did not consider the lower limit of detection (LLoD) to be the mycotoxin level since the actual value could be anywhere below the limit. Instead, half of the LLoD was taken as the mycotoxin level for the present analyses. When results were given as above the upper limit of detection, this upper limit was used as the value in the analyses. These assumptions did not introduce any bias in the dependent response, since 
mycotoxin regulatory limits are within the sensitive range of analytical methods i.e. between lower and upper LoD.

91

92 Kenyan national standards for animal feeds [21,24,25,26,27,28,29,30,31] and human foods

$93[21,32,33,34,35,36,37,38,39,40,41,42,43,44,45,46]$ were applied to categorize the materials

94 as either above or below the maximum admissible levels. Similarly, this was repeated with

95 United States Food and Drugs Administration (FDA) and European Union (EU) standards

$96[1,2,22,47,48,49,50,51,52,53]$. Tables 1 and 2 show the maximum limits (MLs) of seven

97 mycotoxin residues as stipulated in these standards for regulation of contaminants in food and

98 feeds. A sample was considered a mycotoxin or a total aflatoxins hazard if its toxin level was

99 above the legal limit of at least one of the seven mycotoxins referred to as mycotoxins or total 
Table 1. Feed safety regulatory standards used in the study

\begin{tabular}{|c|c|c|c|c|c|c|c|}
\hline \multirow[b]{3}{*}{ Feed matrix } & \multirow[b]{3}{*}{ Toxin } & \multicolumn{6}{|c|}{ Feed safety regulatory standard } \\
\hline & & \multicolumn{2}{|c|}{ KEBS standard } & \multicolumn{2}{|c|}{ US-FDA standard } & \multicolumn{2}{|c|}{ EU standard } \\
\hline & & \begin{tabular}{|l|} 
ML \\
$(p p b)$ \\
\end{tabular} & Reference & $\begin{array}{l}M L \\
(p p b)\end{array}$ & Reference & $\begin{array}{l}M L \\
(p p b)\end{array}$ & Reference \\
\hline Wheat Bran (Feed ingredient) & AFT & 20 & KEBS, 2004 & 20 & \multirow{13}{*}{$\begin{array}{l}\text { FDA, 2019; 2018; } \\
\text { 2017; Alshannaq \& } \\
\text { Yu, 2017; Smith et } \\
\text { al., 2016; South, } 2014\end{array}$} & \multirow{12}{*}{$\mathrm{NSA}^{\mathrm{FT}}$} & \multirow{12}{*}{-} \\
\hline Omena (Feed ingredient) & AFT & 20 & KEBS, 2011a & 20 & & & \\
\hline Cotton Seed/ cake (Feed ingredient) & AFT & 10 & KEBS, 2002 & 20 & & & \\
\hline Sunflower Cake (Feed ingredient) & AFT & 10 & KEBS, 2002 & 20 & & & \\
\hline Maize products (Feed ingredient) & AFT & 10 & $\begin{array}{l}\text { KEBS 2012c, d; } \\
2001\end{array}$ & 20 & & & \\
\hline Wheat Bran (Feed ingredient) & FUM & 2000 & KEBS, 2017 & NS & & & \\
\hline Poultry finished feed & AFT & 10 & KEBS, 2012a & 20 & & & \\
\hline Dog finished feed & AFT & 10 & KEBS, 2012b & 20 & & & \\
\hline Compound feed for dairy cattle & AFT & 10 & KEBS, 2009 & 20 & & & \\
\hline Compound feed for rabbits & AFT & 10 & KEBS 2012e & 20 & & & \\
\hline Compound feed & AFT & 10 & KEBS, 2017 & 20 & & & \\
\hline Fodder feed & AFT & 20 & KEBS, 2019 & 20 & & & \\
\hline Wheat Bran (Feed ingredient) & DON & 1000 & KEBS, 2017 & 5000 & & 8000 & EU, 2006 \\
\hline Wheat Bran (Feed ingredient) & OTA & 5000 & KEBS, 2017 & NS & - & 250 & EU, 2006 \\
\hline Feed ingredient & ZEA & NS & - & NS & - & 2000 & EU, 2006 \\
\hline
\end{tabular}

ML-Maximum level permitted; US-FDA- Food and Drug Administration of the United States of America; KEBS-Kenya Bureau of Standards; ppb-Parts per Billion; NS-not set; AFT-Total aflatoxins; DON-Deoxynivalenol; FUM-Total fumonisins; OTA-Ochratoxin A; ZEA-Zearalenone; NS ${ }^{\text {AFT }}$-EU standard for animal feeds has limit for $\mathrm{AFB}_{1}$ but none for $\mathrm{AFT}$ 
Table 2. Food safety regulatory standards used in the study

\begin{tabular}{|c|c|c|c|c|c|c|c|}
\hline \multirow[b]{2}{*}{ Food matrix } & \multirow[b]{2}{*}{ Toxin } & \multirow[b]{2}{*}{$M L$} & \multirow{2}{*}{$\begin{array}{r}\text { KEBS standard } \\
\text { Reference }\end{array}$} & \multicolumn{2}{|c|}{ US-FDA standard } & \multicolumn{2}{|c|}{ EU standard } \\
\hline & & & & $M L$ & Reference & $M L$ & Reference \\
\hline Baby food & \multirow{7}{*}{ AFT } & \multirow{7}{*}{$10 \mathrm{ppb}$} & KEBS, 2011 & \multirow{7}{*}{$20 \mathrm{ppb}$} & \multirow{7}{*}{$\begin{array}{l}\text { FDA, 2017;Alshannaq } \\
\text { \& Yu, 2017; Smith et } \\
\text { al., 2016; South, } 2014\end{array}$} & $\mathrm{NS}$ & \multirow{7}{*}{$\begin{array}{l}\text { EU, 2010; } \\
\text { Smith et al., 2016; } \\
\text { Pinotti et al., } 2016\end{array}$} \\
\hline Herbal health drink & & & KEBS, 2017 & & & \multirow{6}{*}{$4 \mathrm{ppb}$} & \\
\hline Maize & & & $\begin{array}{l}\text { KEBS, 2018b; 2015a; } \\
2011\end{array}$ & & & & \\
\hline Peanuts & & & KEBS, 2017; 2014b & & & & \\
\hline Sorghum & & & KEBS, 2018c; 2014d, & & & & \\
\hline Tea & & & KEBS, 2017 & & & & \\
\hline Wheat & & & KEBS, 2018d, e; 2011 & & & & \\
\hline Wheat & DON & $1 \mathrm{ppm}$ & KEBS, 2017 & $1 \mathrm{ppm}$ & $\begin{array}{l}\text { FDA, 2018; } \\
\text { Alshannaq \& Yu, } \\
\text { 2017; South, } 2014\end{array}$ & $750 \mathrm{ppb}$ & $\begin{array}{c}\text { EU, 2013; EU, } \\
\text { 2007; Pinotti et al., }\end{array}$ \\
\hline Wheat & $\begin{array}{l}\mathrm{T}-2 \\
\text { toxin }\end{array}$ & NS & - & NS & 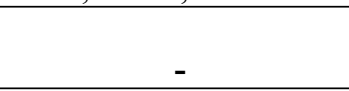 & $100 \mathrm{ppb}$ & 2016 \\
\hline On-the-plate food & \multirow{7}{*}{ AFT } & \multirow{7}{*}{$10 \mathrm{ppb}$} & KEBS, 2015a; 2011a, b & \multirow{7}{*}{$20 \mathrm{ppb}$} & \multirow{7}{*}{$\begin{array}{c}\text { FDA, 2017; } \\
\text { Alshannaq \& Yu, } \\
\text { 2017; Smith et al., } \\
\text { 2016; South, } 2014\end{array}$} & \multirow{4}{*}{$4 \mathrm{ppb}$} & \multirow{7}{*}{$\begin{array}{c}\text { Smith et al., 2016; } \\
\text { Pinotti et al., 2016; } \\
\text { EU, } 2010\end{array}$} \\
\hline Macadamia (other foods) & & & KEBS, 2017 & & & & \\
\hline Barley (other foods) & & & KEBS, 2011b & & & & \\
\hline Beans (other foods) & & & KEBS, 2014e & & & & \\
\hline Chilli (other foods) & & & KEBS, 2017 & & & \multirow[b]{2}{*}{$10 \mathrm{ppb}$} & \\
\hline Macadamia (other foods) & & & KEBS, 2017 & & & & \\
\hline Omena fish (other foods) & & & KEBS, 2011a & & & NS & \\
\hline Dairy products & AFM1 & $500 \mathrm{ppt}$ & $\begin{array}{l}\text { KEBS, 2018a, f; 2017; } \\
\text { 2015b }\end{array}$ & $500 \mathrm{ppt}$ & $\begin{array}{c}\text { Alshannaq \& Yu, } \\
\text { 2017; Smith et al., } \\
\text { 2016; FDA, 2015; } \\
\text { South, } 2014\end{array}$ & $50 \mathrm{ppt}$ & $\begin{array}{l}\text { Alshannaq \& Yu, } \\
\text { 2017; Smith et al., } \\
\text { 2016; EU, } 2010\end{array}$ \\
\hline Baby food & ZEA & MF & KEBS, 2014c & NS & Alshannaq \& Yu, 2017 & $20 \mathrm{ppb}$ & \\
\hline Baby food & DON & MF & KEBS, 2014c & $1 \mathrm{ppm}$ & $\begin{array}{l}\text { FDA, 2018; Alshannaq } \\
\& \text { Yu, 2017; South, } \\
2014\end{array}$ & $200 \mathrm{ppb}$ & $\begin{array}{c}\text { Pinotti et al., 2016; } \\
\text { EU, } 2007\end{array}$ \\
\hline
\end{tabular}

111 ML-Maximum level permitted; MF-Mycotoxin free; US-FDA- Food and Drug Administration of the United States of America; KEBS-Kenya Bureau of Standards; ppm-

112 Parts per Million ppb-Parts per Billion; ppt-Parts per trillion; NS-not set; AFT-Total aflatoxins; AFM1-aflatoxin M1; DON-Deoxynivalenol; ZEA-Zealarenone 


\section{Statistical analysis}

114 Logistic regression analysis was carried out to obtain odds ratios for the dependent response that is, above (1) or below (0) legal limits as stipulated in mycotoxin regulatory standards.

The explanatory variables were 12 different feed/ food commodities and 3 mycotoxin-testing laboratories). The same was repeated for total aflatoxin data where the dichotomous dependent response variable. The mycotoxin and total aflatoxin contamination data had a binomial distribution $(0=$ not hazardous, $1=$ hazardous $), B(n, p)$, where $n=$ number of feed or food samples and $\mathrm{p}=$ probability of attaining hazardous status. The following binary logistic regression model was fitted to both sets of data on statistical computer program (IBM SPSS Statistics 20):

$$
\log \{\mathrm{p} /(1-\mathrm{p}\}=\beta 0+\beta 1 \text { Laboratory }+\beta 2 \text { Food } / \text { Feed matrix }+\varepsilon \mathrm{i}
$$

124 Where, error.

Using the model, the effect of laboratory and feed/ food matrix on the dependent binary outcome variable response was determined. By default, classification cut off value of probability was set at 0.5 , a threshold above and below which the vales are associated with hazardous state and non-hazardous state respectively. Further, the association between material matrices (animal feeds and human foods) and mycotoxin testing laboratories as predictors, and the binary response that is, presence or absence of mycotoxin hazard (either AFT, AFM1, ZEA, T-2 toxin, OTA, FUMS or DON) was further determined employing 


\section{Results}

\section{Frequency of mycotoxin hazards in various animal feed and 139 human food matrices}

140 The failure rates in attaining standards of four feed materials $(n=323)$ and eight food materials $(n=1495)$ tested for total aflatoxins and seven mycotoxins (collectively termed mycotoxins) are given in Table 3. Compound animal feeds were the most contaminated feed matrix with $64 \%$ and $39 \%$ of the 92 samples tested having total aflatoxin levels above the regulatory limit by Kenyan and American standards respectively. Peanuts were the most contaminated human food with $62 \%$ and $47 \%$ of the 180 tested samples having levels above the legal limit by Kenya and American standards respectively for total aflatoxin content. By

147 European standard for total aflatoxin, wheat had the highest contamination rate with $84 \%$ of the 105 samples tested having levels above the regulatory limit. Half $(50 \%)$ of the baby foods failed to meet Kenyan and European standards for total aflatoxins. By Kenyan, American and European standards respectively, maize (a common staple food in Kenya) had total aflatoxin failure rates of 20,14 and $25 \%$ respectively. Again, maize was the most frequently tested food (Table 3). Failure rates of the feed and food samples for the seven different mycotoxins are shown in Table 4. Total aflatoxin was the most frequently tested contaminant followed by aflatoxin M1. In the few samples tested for ochratoxin A and zearalenone, $100 \%$ exceeded the regulatory limits by Kenya standard. Failure rate in dairy products was $60 \%$ according to 
Table 3. Frequency of hazardous mycotoxin contamination in animal feeds and human foods

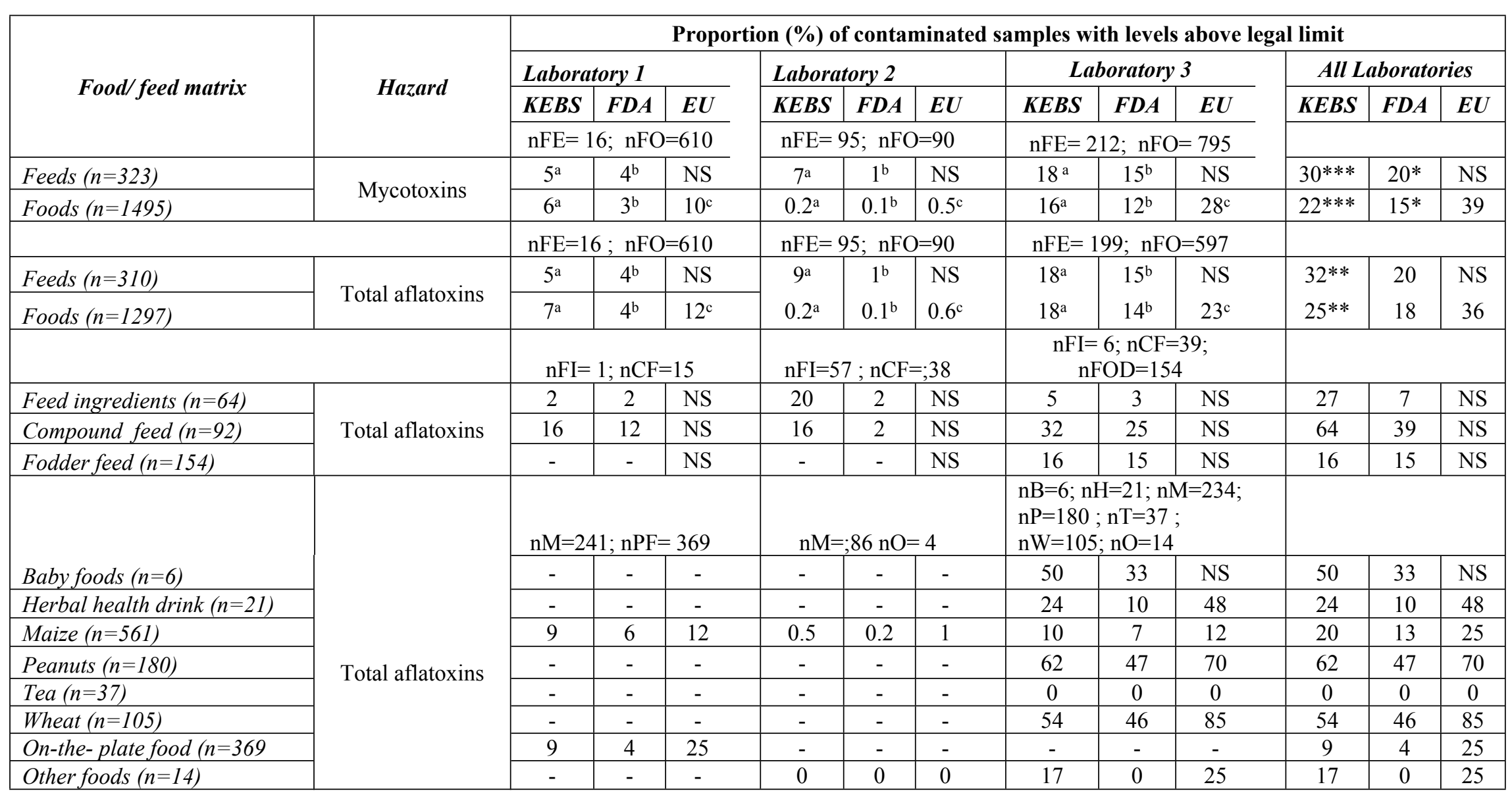

$\mathrm{NS}=$ Regulatory limit not set; $\mathrm{n}_{\mathrm{FE}}, \mathrm{n}_{\mathrm{FO}}, \mathrm{n}_{\mathrm{FI}}, \mathrm{n}_{\mathrm{CF}}, \mathrm{n}_{\mathrm{FOD}}, \mathrm{n}_{\mathrm{B}}, \mathrm{n}_{\mathrm{H}}, \mathrm{n}_{\mathrm{M}}, ; \mathrm{n}_{\mathrm{P}}, ; \mathrm{n}_{\mathrm{T}}, \mathrm{n}_{\mathrm{W}}, \mathrm{n}_{\mathrm{PF}}=$ and $\mathrm{n}_{\mathrm{O}}=$ stand for sample sizes of feed, food, feed ingredient, compound feed, fodder feed, baby food, herbal health drink, maize, peanut, wheat, on-the- plate food and other food respectively. ${ }^{\mathrm{a}}{ }^{\mathrm{b}}$, and ${ }^{\mathrm{c}}$ indicate significant association between laboratory and hazard status at $p=0.001$, whereas $* * *$ and $* * *$ represent significant association between matrix and hazard status respectively at $p=0.05,0.01$ and 0.001 . 
Table 4. Mycotoxins detected in foods and feeds in Kenya (2010-2015)

\begin{tabular}{|c|c|c|c|}
\hline \multirow[b]{2}{*}{ Type of contaminant } & \multicolumn{3}{|c|}{ Proportion (\%) of contaminated samples } \\
\hline & KEBS standard & FDA standard & EU standard \\
\hline Total aflatoxin $(n=1610)$ & 26.29 & 18.14 & 36.02 \\
\hline Aflatoxin M1 $(n=192)$ & 0.52 & 0.52 & 59.9 \\
\hline Deoxynivalenol $(n=6)$ & 0 & 0 & 25 \\
\hline Total fumonisins $(n=6)$ & 0 & 0 & 0 \\
\hline Ochratoxin $A(n=1)$ & $100 *$ & 0 & 0 \\
\hline$T-2 \operatorname{toxin}(n=2)$ & 0 & 0 & 0 \\
\hline Zearalenone $(n=4)$ & $100 *$ & 0 & 25 \\
\hline
\end{tabular}

*Sample size is insufficient

\section{Comparison of mycotoxin hazard rates in animal feed and human food}

Failure rate to attain standards in animal feeds and human foods by mycotoxins and total aflatoxins (AFT) is shown in Table 3. Chi square test of independence showed significant association between both type of matrix and mycotoxin analysing laboratories, and hazards status. By Kenyan standard, animal feeds had higher mycotoxin failure rate (30\%) compared to $22 \%$ in human food $(p<0.001$, Pearson chi square $=16.056, \mathrm{DoF}=2)$ for mycotoxins, and $32 \%$ in animal feeds compared to $25 \%$ in human food $(p<0.01$, Pearson chi square $=7.498$, DoF $=2$ ) for total aflatoxins. By American standard, animal feeds had higher mycotoxin failure rate $(20 \%)$ compared to $15 \%$ in human foods $(p<0.05$, Pearson chi square $=4.328$, DoF $=2$ ) but no significant association was observed for total aflatoxin hazard. There was significant $(p<0.001, \mathrm{DoF}=2)$ association between the various analysing laboratories and hazards status by Kenyan (Pearson chi square $=41.64$ ), American (Pearson chi square $=79.338$ ), and European (Pearson chi square $=141.913$ ) standards for mycotoxins and Pearson chi square $=82.812,119.092$ and 114.23 respectively for total aflatoxins. 
184 Effect of feed and food matrices on frequency of mycotoxin 185 hazards

186 Tables 5-7 show logistic regression results of the two explanatory variables giving odds ratios

187 (OR) of dietary mycotoxin and total aflatoxin hazards occurrence in the matrices and their 188 detection capability as a function of European (EU), American (FDA) and Kenyan (KEBS) standards for regulation of food contaminants. Results of Hosner \& Lemeshow test $(p>0.01)$ indicate good fitting models. Relative to a reference food matrix, high frequency of mycotoxin and total aflatoxin hazards were observed in several food/ feed materials as a 192 function of maximum acceptable contamination limits set by Kenyan, American and 193 European regulatory organizations. By European standard (EU), odds of presence of mycotoxin and total aflatoxin hazards were higher in wheat $(\mathrm{OR}=11.7)$ and $(\mathrm{OR}=14.6)$ respectively, peanuts for both hazards $(\mathrm{OR}=6.1)$, and mycotoxin hazard in dairy products $(\mathrm{OR}=3.9)$ compared to on-the-plate food (Table 5). 
Table 5. Logistic regression results of risks associated with dietary mycotoxins as stipulated in European Union standards for regulation of contaminants foods and feeds

\begin{tabular}{|c|c|c|c|c|}
\hline Mycotoxin & $\begin{array}{c}\text { Mycotoxin-testing } \\
\text { laboratories and Food/ } \\
\text { feed materials }\end{array}$ & $\begin{array}{c}\text { Regression } \\
\text { coefficient (B } \pm \\
\text { S.E) } \\
\end{array}$ & Odds Ratio & $\begin{array}{l}95 \% \text { CI } \\
\text { Odds } \\
\text { Ratio }\end{array}$ \\
\hline \multirow{11}{*}{$\begin{array}{c}\text { Any one } \\
\text { mycotoxin } \\
\text { (AFT, } \\
\text { AFM1, } \\
\text { ZEA, T-2 } \\
\text { toxin, } \\
\text { OTA, } \\
\text { FUMS, } \\
\text { DON)) }\end{array}$} & Lab1 (610) & $-0,15 \pm 0.20$ & 0.86 & $0.58-1.28$ \\
\hline & Lab2 (90) & $-1.49 \pm 0.40^{* * *}$ & 0.23 & $0.1-0.49$ \\
\hline & Baby foods (8) & $0.45 \pm 0.77$ & 1.57 & $0.35-7.08$ \\
\hline & Dairy products (192) & $1.37 \pm 0.28^{* * *}$ & 3.92 & $2.27-6.76$ \\
\hline & Herbal health drink (21) & $0.87 \pm 0.50$ & 2.38 & $0.9-6.31$ \\
\hline & Maize (561) & $0.12 \pm 0.19$ & 1.13 & $0.78-1.63$ \\
\hline & Peanuts (180) & $1.81 \pm 0.29^{* *}$ & 6.12 & $3.49-10.74$ \\
\hline & Tea (37) & $-20.24 \pm 6607.68$ & $1.62 \times 10^{-9}$ & - \\
\hline & Wheat (109) & $2.46 \pm 0.34 * * *$ & 11.67 & $5.97-22.82$ \\
\hline & Other foods (12) & $0.24 \pm 0.73$ & 1.27 & $0.31-5.26$ \\
\hline & $\begin{array}{l}\text { Reference: Lab } 3 \text { (789)/on- } \\
\text { the-plate (369) }\end{array}$ & $-0.96 \pm 0.24 * * *$ & 0.38 & \\
\hline \multirow{10}{*}{$\begin{array}{c}\text { Total } \\
\text { aflatoxins }\end{array}$} & Lab1 (610) & $-0.15 \pm 0.20$ & 0.86 & $0.58-1.28$ \\
\hline & Lab2 (90) & $-1.49 \pm 0.40^{* * *}$ & 0.23 & $0.10-0.49$ \\
\hline & Baby foods (6) & $0.96 \pm 0.85$ & 2.62 & $0.50-13.87$ \\
\hline & Herbal health drink (21) & $0.87 \pm 0.50$ & 2.38 & $0.90-6.31$ \\
\hline & Maize (561) & $0.12 \pm 0.19$ & 1.13 & $0.78-1.63$ \\
\hline & Peanuts (180) & $1.81 \pm 0.29 * * *$ & 6.12 & $3.49-10.74$ \\
\hline & Tea (37) & $-20.24 \pm 6607.68$ & $1.62 \times 10^{-9}$ & - \\
\hline & Wheat (105) & $2.68 \pm 0.36^{* * *}$ & 14.59 & $7.20-29.54$ \\
\hline & Other foods (12) & $0.24 \pm 0.73$ & 1.27 & $0.31-5.26$ \\
\hline & $\begin{array}{l}\text { Reference: Lab } 3(591) / \text { on- } \\
\text { the-plate }(369)\end{array}$ & $-0.96 \pm 0.24^{* * *}$ & 0.38 & \\
\hline
\end{tabular}

221

$* \mathrm{p}<0.05 ; \quad * * \quad \mathrm{p}<0.01 ; \quad * * * \quad \mathrm{p}<0.001 ; \quad \mathrm{NS}=\mathrm{p}$-value not significant; AFT=Total aflatoxins; AFM1=Aflatoxin $\mathrm{M1}$; ZEA=Zearalenone; OTA=Ochratoxin A; FUMS=Total fumonisins; DON=Deoxynivalenol

By the American standard (FDA), the odds of detecting mycotoxin and total aflatoxin hazards were higher in compound feeds $(\mathrm{OR}=31.3,32.6$ respectively), and fodder feeds $(\mathrm{OR}=8.3$, 9.7 respectively) compared to on-the-plate food. In human foods, the odds of presence of mycotoxin and total aflatoxin hazards were higher in peanuts $(\mathrm{OR}=17.1,16.9$ respectively $)$, wheat $(\mathrm{OR}=18.0,15.9)$, maize $(\mathrm{OR}=3.9,3.8$ respectively $)$ and baby foods $(\mathrm{OR}=7.7,9.4$ 
Table 6. Logistic regression results of risks associated with dietary mycotoxins as stipulated in Food \& Drug administration of United States of America (FDA) standards for regulation of contaminants in foods and feeds

\begin{tabular}{|c|c|c|c|c|}
\hline Mycotoxin & $\begin{array}{c}\text { Mycotoxin-testing } \\
\text { laboratories and Food/ feed } \\
\text { materials }\end{array}$ & $\begin{array}{c}\text { Regression } \\
\text { coefficient ( } \mathrm{B} \pm \\
\text { S.E) }\end{array}$ & $\begin{array}{l}\text { Odds } \\
\text { Ratio }\end{array}$ & $\begin{array}{c}\text { 95\% CI } \\
\text { Odds Ratio }\end{array}$ \\
\hline \multirow{14}{*}{$\begin{array}{c}\text { Any one } \\
\text { mycotoxin } \\
\text { (AFT, } \\
\text { AFM1, } \\
\text { ZEA, T-2 } \\
\text { toxin, } \\
\text { OTA, } \\
\text { FUMS, } \\
\text { DON)) }\end{array}$} & Lab1 (626) & $-0.14 \pm 0.23$ & 0.87 & $0.55-1.36$ \\
\hline & Lab2 (180) & $-3.20 \pm 0.57 * * *$ & 0.04 & $0.01-0.12$ \\
\hline & Baby foods (7) & $2.03 \pm 0.90^{*}$ & 7.65 & $1.30-45.06$ \\
\hline & Dairy products (192) & $-2.30 \pm 1.06^{*}$ & 0.1 & $0.01-0.80$ \\
\hline & Feed Ingredients (59) & $2.12 \pm 0.75^{* *}$ & 8.31 & $1.89-36.45$ \\
\hline & Compound feeds (93) & $3.44 \pm 0.41 * * *$ & 31.26 & $14.1-69.34$ \\
\hline & Fodder feeds (154) & $1.21 \pm 0.41^{* *}$ & 3.36 & $1.50-7.53$ \\
\hline & Herbal health drink (21) & $0.70 \pm 0.82$ & 2.01 & $0.40-10.03$ \\
\hline & Maize (561) & $1.35 \pm 0.31 * * *$ & 3.89 & $2.11-7.08$ \\
\hline & Peanuts (180) & $2.84 \pm 0.38^{* * *}$ & 17.1 & $8.19-35.73$ \\
\hline & Tea (37) & $-18.25 \pm 6607.68$ & $1.18 \times 10-10$ & - \\
\hline & Wheat (107) & $2.74 \pm 0.40^{* * *}$ & 15.55 & $7.16-33.79$ \\
\hline & Other foods (18) & $-17.92 \pm 9047.27$ & $1.65 \times 10^{-8}$ & - \\
\hline & $\begin{array}{l}\text { Reference: Lab } 3 \text { (992)/ on- } \\
\text { the-plate (369) }\end{array}$ & $-2.95 \pm 0.34 * * *$ & 0.05 & \\
\hline \multirow{13}{*}{$\begin{array}{c}\text { Total } \\
\text { aflatoxins }\end{array}$} & Lab1(626) & $-0.16 \pm 0.23$ & 0.86 & $0.54-1.35$ \\
\hline & Lab2 (180) & $-3.27 \pm 0.57 * * *$ & 0.04 & $0.01-0.12$ \\
\hline & Baby foods (6) & $2.24 \pm 0.93^{* *}$ & 9.43 & $1.52-58.64$ \\
\hline & Feed Ingredients (58) & $2.27 \pm 0.77^{* *}$ & 9.7 & $2.16-43.65$ \\
\hline & Compound feeds (92) & $3.48 \pm 0.41 * * *$ & 32.62 & $14.64-72.66$ \\
\hline & Fodder feeds (154) & $1.20 \pm 0.41^{* *}$ & 3.31 & $1.48-7.44$ \\
\hline & Herbal health drink (21) & $0.69 \pm 0.82$ & 1.99 & $0.40-9.90$ \\
\hline & Maize (561) & $1.35 \pm 0.31^{* * *}$ & 3.84 & $2.10-7.04$ \\
\hline & Peanuts (180) & $2.83 \pm 0.38 * * *$ & 16.88 & $8.08-35.27$ \\
\hline & Tea (37) & $-18.27 \pm 6607.68$ & $1.17 \times 10^{-8}$ & - \\
\hline & Wheat (105) & $2.77 \pm 0.40 * * *$ & 15.89 & $7.30-34.58$ \\
\hline & Other foods (18) & $-17.93 \pm 9034.86$ & $1.63 \times 10^{-8}$ & - \\
\hline & $\begin{array}{l}\text { Reference: Lab 3(795) + on- } \\
\text { the-plate (369) }\end{array}$ & $-2.94 \pm 0.35 * * *$ & 0.05 & \\
\hline
\end{tabular}


260 For the Kenya standard (KEBS), odds of presence of mycotoxin and total aflatoxin hazards

261 were higher in feed ingredients $(\mathrm{OR}=17.9,24.3$ respectively), in compound feeds $(\mathrm{OR}=$

$26241.8,47.8$ respectively), peanuts $(\mathrm{OR}=16.9,16.3$ respectively), wheat $(\mathrm{OR}=12.0)$, baby

263 foods $(\mathrm{OR}=10.5,10.1$ respectively $)$ and maize $(\mathrm{OR}=2.9)$ compared to on-the-plate food.

264 Odds of herbal health drink are more prone to the two hazards ( $\mathrm{OR}=3.3,3.2$ respectively),

265 while odds of presence of mycotoxin hazard were lower in dairy products $(\mathrm{OR}=0.05)$

266 compared to on-the-plate food (Table 7). 
Table 7. Logistic regression results of risks associated with dietary mycotoxins as stipulated in Kenya (KEBS) standards for regulation of contaminants in foods and feeds

\begin{tabular}{|c|c|c|c|c|}
\hline Mycotoxin & $\begin{array}{c}\text { Mycotoxin-testing } \\
\text { laboratories and Food/ } \\
\text { feed materials }\end{array}$ & $\begin{array}{c}\text { Regression } \\
\text { coefficient (B } \pm \\
\text { S.E) } \\
\end{array}$ & $\begin{array}{l}\text { Odds } \\
\text { Ratio }\end{array}$ & $\begin{array}{c}95 \% \text { CI } \\
\text { Odds Ratio }\end{array}$ \\
\hline \multirow{14}{*}{$\begin{array}{c}\text { Any one } \\
\text { mycotoxin } \\
\text { (AFT, } \\
\text { AFM1, } \\
\text { ZEA, T-2 } \\
\text { toxin, } \\
\text { OTA, } \\
\text { FUMS, } \\
\text { DON)) }\end{array}$} & Lab1 (626) & $0.06 \pm 0.21$ & 1.06 & $0.71-1.61$ \\
\hline & Lab2 (185) & $-1.82 \pm 0.33^{* * *}$ & 0.16 & $0.08-0.31$ \\
\hline & Baby foods (8) & $2.35 \pm 0.76^{* * *}$ & 10.49 & $2.37-46.44$ \\
\hline & Dairy products (192) & $-2.90 \pm 1.04 * *$ & 0.05 & $0.01-0.42$ \\
\hline & Feed Ingredients (66) & $2.88 \pm 0.46^{* * *}$ & 17.9 & $7.29-43.93$ \\
\hline & Compound feeds (93) & $3.73 \pm 0.37^{* * *}$ & 41.82 & $20.22-86.46$ \\
\hline & Fodder feeds (154) & $0.66 \pm 0.35$ & 1.94 & $0.97-3.88$ \\
\hline & Herbal health drink (21) & $1.19 \pm 0.58^{*}$ & 3.28 & $1.05-10.26$ \\
\hline & Maize (561) & $1.07 \pm 0.23^{* * *}$ & 2.93 & $1.85-4.63$ \\
\hline & Peanuts (180) & $2.83 \pm 0.32 * * *$ & 16.87 & $9.08-31.34$ \\
\hline & Tea (37) & $-18.85 \pm 6607.68$ & $\underset{9}{6.49 \times 10^{-}}$ & - \\
\hline & Wheat (107) & $2.48 \pm 0.34 * * *$ & 11.96 & $6.17-23.17$ \\
\hline & Other foods (18) & $0.50 \pm 0.81$ & 1.65 & $0.34-8.00$ \\
\hline & $\begin{array}{l}\text { Reference: Lab 3(995)+ } \\
\text { on-the-plate (369) }\end{array}$ & $-2.35 \pm 0.28 * * *$ & 0.10 & \\
\hline \multirow{13}{*}{$\begin{array}{c}\text { Total } \\
\text { aflatoxins }\end{array}$} & Lab1 (626) & $0.03 \pm 0.21$ & 1.03 & $0.68-1.56$ \\
\hline & Lab2. (180) & $-2.05 \pm 0.36^{* * *}$ & 0.13 & $0.06-0.26$ \\
\hline & Baby foods (6) & $2.32 \pm 0.86^{* *}$ & 10.14 & $1.87-54.95$ \\
\hline & Feed Ingredients (62) & $3.19 \pm 0.49^{* * *}$ & 24.29 & 9.24-63.85 \\
\hline & Compound feeds (92) & $3.87 \pm 0.39 * * *$ & 47.82 & $22.44-101.9$ \\
\hline & Fodder feeds (154) & $0.63 \pm 0.36$ & 1.87 & $0.93-3.76$ \\
\hline & Herbal health drink (21) & $1.15 \pm 0.58^{*}$ & 3.17 & $1.01-9.92$ \\
\hline & Maize (561) & $1.07 \pm 0.23^{* * *}$ & 2.9 & $1.83-4.60$ \\
\hline & Peanuts (180) & $2.79 \pm 0.32 * * *$ & 16.31 & $8.77-30.34$ \\
\hline & Tea (37) & $-18.87 \pm 6607.68$ & $\begin{array}{r}62.8 \\
\times 10^{-6} \\
\end{array}$ & - \\
\hline & Wheat (105) & $2.49 \pm 0.34 * * *$ & 12.04 & $6.19-23.42$ \\
\hline & Other foods (18) & $0.48 \pm 0.81$ & 1.61 & $0.33-7.84$ \\
\hline & $\begin{array}{l}\text { Reference: Lab 3(794)+ } \\
\text { on-the-plate (369) }\end{array}$ & $-2.32 \pm 0.28 * * *$ & 0.10 & \\
\hline
\end{tabular}

283 


\section{Hazard detection capacity by mycotoxin-testing laboratories}

290 Further evidence suggests difference in hazard detection ability by different mycotoxin-

291 testing facilities. Odds of detection by Lab2 were lower for mycotoxin and total aflatoxin

292 hazards by EU $(\mathrm{OR}=0.2)$, FDA $(\mathrm{OR}=0.04)$ and $\mathrm{KEBS}(\mathrm{OR}=0.2,0.1$ respectively) standards compared to reference laboratory (Lab3) (Tables 5 and 6). No difference was observed between Lab1 and Lab3 (Tables 5-7).

\section{Discussion}

We used USA and European Union food contaminants regulatory systems in the present study because of their robust and strict nature, and regular interaction with the Kenyan economy. High frequency of mycotoxin hazards in food and feed materials with highest frequency in compound feeds, feed ingredients, peanuts and wheat in that order was observed. This agrees with other authors' observation that animals are frequently fed more contaminated products compared to humans $[54,55,56]$. In resource poor environments, biomass considered unfit for human consumption is commonly used for feeding animals to avoid waste. Presence of mycotoxin hazards in animal feeds and foods is of great concern since chronic dietary mycotoxicosis is associated with adverse health effects including immune dysfunction, nutritional deficiency, reduced fertility, drug and vaccine failure, and pathological and metabolic aberrations [4,7,57,58,59,60,61]. Mycotoxins impair productivity in farm animals $[9,56,62]$ resulting in economic loss $[1,63]$. They carry-over to animal edible products [13], and are an impediment to international trade [1,2,64] since there is increasing demand for safe foods [14]. 
312 We identified peanuts and wheat as the human foods with significant frequency of mycotoxin

313 and total aflatoxin hazards. High frequency of total aflatoxin hazard in maize and baby foods, herbal health drinks and aflatoxin M1, a hydroxylated metabolite of aflatoxin B1, in dairy products was also observed. These are readily available processed, raw and staple food items commonly consumed by both children and adults. In Africa and more so in Kenya, many foods such as cereals and dairy products although not generally classified as baby foods, are actually consumed by infants and young children. Some of the mycotoxins encountered in the present study for instance aflatoxins, ochratoxin A and fumonisins are teratogenic, carcinogenic, mutagenic, nephrotoxic, hepatotoxic and immunosuppressive in humans and animals $[1,4,8,17,65,66]$. Aflatoxin is anti-nutritional [10], and could be associated with childhood stunting and $[11,12,13,14]$ in humans. Besides exerting direct toxicological effects, mycotoxins are also known to induce oncogenesis in synergy with human pathogens. The most abundant of the observed hazards, aflatoxins could have serious implication in aetiology and epidemiology of malignancies in human population. Its involvement in development of primary hepatocellular carcinoma through synergy with hepatitis B virus is well documented $[67,68]$, and interaction with human papillomavirus in induction of oesophageal malignancy postulated [54,69]. Mycotoxins are known to modify disease through aggravation of pathogenesis of viral, bacterial, and parasitic infections in humans and experimental animals $[6,70,71]$. Of special interest is exacerbation of mucosa-associated diseases in the gastrointestinal and respiratory tracts by mycotoxins [70].

Cancer is an increasingly emerging health scourge in Sub-Saharan Africa [72,73] and major cause of death, ranking third with 28500 deaths and increased incidence reaching 37000 new cases during 2012 in Kenya [54,74,75] and more alarmingly in relatively young people [76]. 
In Kenya, the mean age of easophageal malignancy patients is approximately 50 years with

337 high numbers of patients below 40 years. Our data show high frequency of mycotoxin hazards in foods destined for consumption by paediatric and pregnant individuals suggesting that exposure to the dietary carcinogenic hazards in Kenyan human population commences early in life. In fact, in utero mycotoxin exposure is not uncommon in Sub-Saharan Africa [18]. Since malignancy depends on exposure in terms of dose and time [77], with the young being more susceptible to environmental carcinogens [78,79] and more so to mycotoxins $[59,80]$, our observation points to a possible important risk factor contributing to occurrence of cancer in relatively young individuals and human population as a whole in Kenya.

Oncogenesis can be induced via reduced immuno-surveillance [81] or potentiation of established as human carcinogens are associated with some prevalent malignancies in Kenya [82] such as esophageal, stomach, liver, prostate, breast, cervical, ovarian cancers, chronic leukemia, endometrial, laryngeal, colorectal, nasopharyngeal, Kaposi's sarcoma and nonHodgkin's lymphoma cancers $[54,75,83,84,85,86]$. High frequency of mycotoxins observed in the present study, could likely be an important risk factor in development of these infection-associated malignancies through either synergy, exacerbation of the carcinogenic infections or immunosuppression. Further studies are required to elucidate the relationship between the carcinogenic biological agents and chronic exposure to dietary mycotoxin hazards. Exposure to mycotoxins in children at a young age has been reported before in authorities to protect vulnerable individuals from these lethal toxins. 
The present study was not designed to assess laboratories' ability to detect mycotoxins. We however observed significant difference in probability of failure for mycotoxin regulatory limits reported by the three laboratories. This could be explained by differences in analytical methods applied by the laboratories, differences in primary sampling procedures, or bias in terms of samples sent to each laboratory. Two of the laboratories which provided the mycotoxin contamination retrospective data, are private entities and most of their samples were collected and delivered for analysis by clients while samples for the third laboratory were collected by researchers. Heterogeneous distribution of mycotoxin contamination in food and feed materials necessitates employment of appropriately designed and applied procedures for representative sampling [87] and there is no guarantee that the sample were representative since this information was not provided. Further, the purposes for analysis were varied ranging from research, routine monitoring to outbreak of gastrointestinal conditions. It was noted that maize, and total aflatoxin were respectively the most frequently tested food matrix and mycotoxin. All this could introduce a bias in the present study. Consequently, the sample sizes were in most cases inadequate and some important food items and mycotoxins were left out in the present study. Also, the analytical methodology employed by the laboratories were mostly enzyme immunoassays with different limits of detection and quantification, sensitivity and specificity, and were not necessarily those recommended by the food contaminants regulatory organizations. Nevertheless, our data provide a credible evidence of a possible scenario for exposure to dietary mycotoxin hazards.

Lastly, we noticed some areas in the national mycotoxin regulation standards that require some revision. The European standard is quite strict with very low legal limits. For example the maximum limit for aflatoxin M1 in processed dairy products by Kenyan [21,32,37,39] American [50] and FAO/ WHO's/ Codex Alimentarius [88] is 10-fold (500 ppt) compared to 
the European standard of $50 \mathrm{ppt}$ [52]. The latter further set the limit to $25 \mathrm{ppt}$ for the toxin in infant formulae and milk all this adequately protecting infants and young children. We further observed that many food and feed items consumed locally are not covered by the safety standards. International standards, mostly Codex Alimentarius are adopted in their original version without tailoring them for local scenario. Further, although there is high likelihood of some mycotoxin hazards such as ochratoxin $\mathrm{A}$, zearalenone and $\mathrm{T}-2$ toxin, we found no mention of their legal limits set in the national regulatory standards. These agree with Matumba et al. [89] and Trench et al. [14] who observed that, although various mycotoxins are found in developing countries, more emphasis is put on aflatoxins. In addition, enforcement of mycotoxin regulatory standards is rare in developing countries $[23,90]$. Protection of population from dietary contaminants, is a function of both establishment of sound regulatory limits and their effective enforcement, and whose driving force lies in a balance between health benefits and food security concerns. In Sub-Saharan Africa, where there is rampant food scarcity, the desire to feed increasing populations erroneously outweighs the health benefits of mycotoxin regulation. High frequency of mycotoxin contamination in Sub-Saharan Africa should be enough incentive for more strict regulation in the region. Nevertheless, recent proposal to review aflatoxin limits by KEBS at the East African Community platform is a welcome move.

\section{Conclusions}

We conclude that animals and humans, including infants, young children and expectant mothers, in Kenya are exposed to an array of dangerous dietary mycotoxin hazards which could lead to serious economic and health implications including cancer. Active surveillance of all dietary mycotoxin hazards observed in this study should be enhanced employing 
representative sampling plans. More often, concurrent contamination by more than one mycotoxin occurs including masked mycotoxins whose data were not included in the present study. Regulation and future research should therefore focus on multi-mycotoxin analysis

412 techniques, collection of data on toxicological effects of concurrent mycotoxin contamination

413 and consumption pattern, and regulatory limits accordingly set and compliance enforced to 414 protect vulnerable demographic groups such as paediatric, geriatric and sick members of the society.

\section{Acknowledgements}

418 The Director General (KALRO) and Deputy Director General (Livestock Research) granted permission to publish these data. We thank the mycotoxin-testing laboratories, KALRO-Food providing the data used in this study. Mr. Phochunatus Sifuna (KALRO), Mr. George Kimani (Bora Biotech Ltd) and Mr. Charles Maina (Polucon Services (K) Ltd, compiled these data. Mr. David Kinoti and M/s Joana Auma (KALRO) kindly provided statistical and reference management programs respectively. Mr. Nicholus Ndiwa (ILRI) offered training on use of SPSS statistical program. A former science teacher, Mr. R. S. I. Karuku is highly acknowledged posthumously for inspiring the first author to the world of food poisoning, which is the main drive in this communication. 


\section{References}

1. Alshannaq A, Yu J-H (2017) Occurrence, toxicity, and analysis of major mycotoxins in food. Int J Environ Res Public Health 14.

2. Pinotti L, Ottoboni M, Giromini C, Dell'Orto V, Cheli F (2016) Mycotoxin contamination in the EU feed supply chain: a focus on cereal by-products. Toxins 824 pages.

3. Okoth S, Nyongesa B, Ayugi V, Kang'ethe E, Korhonen H, et al. (2012) Toxigenic potential of Aspergillus species occurring on maize kernels from two agro-ecological zones in Kenya. Toxins 4: 991-1007.

4. Akande KE, Abubakar MM, Adegbola TA, Bogoro SE (2006) Nutritional and health implications of mycotoxins in animal feeds: A review. Pakistan Journal of Nutrition 5: 398-403.

5. Wild CP, Mykkänen H, Amra H, Abdel-Wahhab M, Sylla A, et al. (2008) Urinary biomarkers of aflatoxin exposure in young children from Egypt and Guinea. Food and Chemical Toxicology 46: 519-526.

6. Kibugu JK, Ngeranwa JJN, Makumi JN, Gathumbi JK, Kagira JM, et al. (2009) Aggravation of pathogenesis mediated by ochratoxin A in mice infected with Trypanosoma brucei rhodesiense. Parasitology 136: 273-281.

7. Williams JH, Phillips TD, Jolly PE, Stiles JK, Jolly CM, et al. (2004) Human aflatoxicosis in developing countries: a review of toxicology, exposure, potential health consequences and interventions. American Journal of Clinical Nutrition 80: 1106-1122.

8. WHO, IARC (2002) IARC monographs on the evaluation of carcinogenic risks to humans: some traditional herbal medicines, some mycotoxins, naphthalene and styrene. World Health Organization/ International Agency for Research on Cancer

Lyon, France: IARC Press. pp. 1-590.

9. Dilkin P, Zorzete P, Mallmann CA, Gomes JDF, Utiyama CE, et al. (2003) Toxicological effects of chronic low doses of aflatoxin B1 and fumonisin B1-containing Fusarium moniliforme culture material in weaned piglets. Food and Chemical Toxicology 41: 1345-1353.

10. Tang L, Xu L, Afriyie-Gyawu E, Liu W, Wang P, et al. (2009) Aflatoxin-albumin adducts and correlation with decreased serum levels of vitamins $A$ and $E$ in an adult Ghanaian population. Food additives \& contaminants Part A, Chemistry, analysis, control, exposure \& risk assessment 26: 108-118.

11. Wu F (2013) Aflatoxin exposure and chronic human diseases: estimates of burden of disease. In: Unnevehr L, Grace D, editors. Aflatoxins Finding solutions for improved food safety. Washington, DC 20006-1002 USA: International Food Policy Research Institute (IFPRI. 2033 K Street, NW. pp. 12-13.

12. Leroy JL (2013) Child stunting and aflatoxins. In: Unnevehr L, Grace D, editors. Aflatoxins Finding solutions for improved food safety. Washington: International Food Policy Research Institute (IFPRI. 2033 K Street, NW, Washington, DC 20006-1002 USA. . pp. 14-15. 
13. Volkel I, Schröer-Merker E, Czerny C-P (2011) The carry-over of mycotoxins in products of animal origin with special regard to its implications for the European food safety legislation. Food and Nutrition Sciences 2: 852-867.

14. Trench PC, Narrod C, Roy D, Tiongco M (2011) Responding to health risks along the value chain. 2020 Conference: Leveraging Agriculture for Improving Nutrition and Health. New Delhi, India: International Food Policy Research Institute (IFPRI). pp. 54 pages.

15. Kang'ethe E (2011) Situation analysis: improving food safety in the maize value chain in Kenya. Nairobi, Kenya.: Food and Agriculture Organization (FAO). 89 p.

16. Probst C, Njapau H, Cotty PJ (2007) Outbreak of an acute aflatoxicosis in Kenya in 2004: identification of the causal agent. Applied and Environmental Microbiology 73: 2762-2764.

17. Peraica M, Radic B, Lucic A, Pavlovic M (1999) Toxic effects of mycotoxins in humans. Bulletin of the World Health Organization 77: 754-766.

18. Turner PC, Collinson AC, Cheung YB, Gong YY, Hall AJ, et al. (2007) Aflatoxin exposure in utero causes growth faltering in Gambian infants. International Journal of Epidemiology 36: 1119-1125.

19. Obade $M$, Andang'o P, Obonyo C, Lusweti $F$ (2015) Exposure of children 4 to 6 months of age to aflatoxin in Kisumu County, Kenya. African Journal of Food, Agriculture, Nutrition and Development 15: 9949-9963.

20. Keskin Y, R. B, Karsli S, Yurdun T, Ozyaral O (2009) Detection of aflatoxin M1 in human breast Milk and raw cow's Milk in Istanbul, Turkey. Journal of Food Protection 72 885-889.

21. KEBS (2017) General standard for contaminants in feeds and foods. 1st Edition. Nairobi: Kenya Bureau of Standards (KEBS).

22. Smith M-C, Madec S, Coton E, Hymery N (2016) Natural co-occurrence of mycotoxins in foods and feeds and their in vitro combined toxicological effects. Toxins 8.

23. Ferrão J, Bell V, Fernandes TH (2017) Mycotoxins, food safety and security in Sub-Saharan Africa. SM J Food Nutri Disord 3: 1021.

24. KEBS (2019) Fodder hay-Specifications. Part 1: Grass hay. 1st Edition. 1st ed. Nairobi: Kenya Bureau of Standards (KEBS).

25. KEBS (2012a) Compounded poultry feeds - Specification. 1st Edition 2012. 1st ed. Nairobi: Kenya Bureau of Standards ( KEBS).

26. KEBS (2012b) Dog feeds - Specification. 1st Edition. 1st ed. Nairobi: Kenya Bureau of Standards (KEBS).

27. KEBS (2012c) Maize gluten feed - Specification. 2nd Edition. 2nd ed. Nairobi: Kenya Bureau of Standards (KEBS).

28. KEBS (2012d) Maize gluten meal - Specification. 1st Edition. 1st ed. Nairobi: Kenya Bureau of Standards (KEBS). 
29. KEBS (2012e) Rabbit feed supplements-Specification. 1st Edition 2012. 1st ed. Nairobi: Kenya Bureau of Standards (KEBS).

30. KEBS (2004) Wheat bran for animal feeds - Specification. 1st Edition 2004 1st ed. Nairobi: Kenya Bureau of Standards (KEBS).

31. KEBS (2001) Maize bran as a livestock feed- Specification. 1st Edition 2001. 1st ed. Nairobi: Kenya Bureau of Standards (KEBS).

32. KEBS (2018a) Dairy creams and prepared creams- Specification. 23rd Edition 2018. Nairobi: Kenya Bureau of Standards (KEBS).

33. KEBS (2018b) Maize grains -Specification. 2nd Edition 2018. Nairobi: Kenya Bureau of Standards (KEBS).

34. KEBS (2018c) Sorghum flour - Specification. 2nd Edition 2018. Nairobi: Kenya Bureau of Standards (KEBS).

35. KEBS (2018d) Wheat flour- Specification. 1st Edition 2018. 1st ed. Nairobi: Kenya Bureau of Standards (KEBS).

36. KEBS (2018e) Wheat grains - Specification. 2nd Edition 2018. 2nd ed. Nairobi: Kenya Bureau of Standards (KEBS).

37. KEBS (2018f) Fermented (cultured) milks- Specification. 3rd Edition 2018. 3rd ed. Nairobi: Kenya Bureau of Standards (KEBS).

38. KEBS (2015a) Fortified milled maize (corn) products - Specification. Nairobi: Kenya Bureau of Standards (KEBS).

39. KEBS (2015b) Cheese- Specification, Part 1: General requirements. 3rd Edition 2015. 3rd ed. Nairobi: Kenya Bureau of Standards (KEBS).

40. KEBS (2014a) Infant formula-Specification. 1st Edition 2014. 1st ed. Nairobi: Kenya Bureau of Standards (KEBS).

41. KEBS (2014b) Peanut butter-Specification. 1st Edition 2014. Nairobi: Kenya Bureau of Standards (KEBS).

42. KEBS (2014c) Processed cereal-based foods for infants and young children- Specification. 1st Edition 2014. 1st ed. Nairobi: Kenya Bureau of Standards (KEBS).

43. KEBS (2014d) Sorghum grains- Specification. 1st Edition 2014. Nairobi: Kenya Bureau of Standards (KEBS).

44. KEBS (2014e) Faba beans- Specification. 1st Edition 2014. Nairobi: Kenya Bureau of Standards (KEBS).

45. KEBS (2011a) Dried rastrineobola argentea (omena/ dogaci/ mukene). 2nd Edition 2011. 2nd ed. Nairobi: Kenya Bureau of Standards (KEBS).

46. KEBS (2011b) Milled cereals and pulses products - Specification. 1st Edition 2011. 1st ed. Nairobi: Kenya Bureau of Standards (KEBS). 
47. FDA (2019) Sec. 683.100 Action levels for aflatoxins in animal food. U.S. Department of Health and Human Services Food and Drug Administration Office of Regulatory Affairs and Center for Veterinary Medicine.

48. FDA (2018) Guidance for Industry and FDA: advisory levels for deoxynivalenol (DON) in finished wheat products for human consumption and grains and grain by-products used for animal feed. July 2010: US Food and Drugs Administration.

49. FDA (2017) Guidance for Industry: Action Levels for Poisonous or Deleterious Substances in Human Food and Animal Feed. August 2000: U.S. Department of Health and Human Services, US Food and Drugs Administration.

50. FDA (2015) Compliance policy guide (CPG Sec. 527.400). Whole milk, low fat milk, skim Milk Aflatoxin M1. 2005 ed: U.S. Department of Health and Human Services Food and Drug Administration.

51. South P (2014) FDA's regulatory program for chemical contaminants in foods. Food and Drug Administration 2014 JIFSAN/FDA Food \& Nutrition Webinar. Office of Food Safety Center for Food Safety and Applied Nutrition. pp. 42 pages.

52. EU (2010) Amending Regulation (EC) No 1881/2006 setting maximum levels for certain contaminants in foodstuffs as regards aflatoxins. Commission regulation (EU) No 165/2010 of 26 February 2010. Official Journal of the European Union 27.2.2010: L 50/58- L $50 / 12$.

53. EU (2007) Amending Regulation (EC) No 1881/2006 setting maximum levels for certain contaminants in foodstuffs as regards Fusarium toxins in maize and maize products. Commission regulation (EC) No 1126/2007 of 28 September 2007. Official Journal of the European Union 29.9.2007: L 255/214- L 255/217.

54. Kigen G, Busakhala N, Kamuren Z, Rono H, Kimalat W, et al. (2017) Factors associated with the high prevalence of oesophageal cancer in Western Kenya: a review. Infectious Agents and Cancer 12: 59.

55. Kang'ethe EK, Korhonen H, Marimba KA, Nduhiu G, Mungatu JK, et al. (2017) Management and mitigation of health risks associated with the occurrence of mycotoxins along the maize value chain in two counties in Kenya. Food Quality and Safety 1: 268-274.

56. Grace D (2013) Animals and aflatoxins. In: Unnevehr L, Grace D, editors. Aflatoxins- Finding solutions for improved food safety. Washington, DC 20006-1002 USA: International Food Policy Research Institute (IFPRI. 2033 K Street, NW. pp. 16-17.

57. Indresh HC, Devegowda G, Ruban SW, Shivakumar MC (2013) Effects of high grade bentonite on performance, organ weights and serum biochemistry during aflatoxicosis in broilers. Vet World 6: 313-317.

58. Kaki S, Moeini MM, Cheraghi J (2012) Effects of zeolite and mycosorb on serum biochemical and hematological parameters of broilers chicken aflatoxicosis. J Blood Lymph 2: 105.

59. Andretta I, Kipper M, Lehnen CR, Lovatto PA (2012) Meta-analysis of the relationship of mycotoxins with biochemical and hematological parameters in broilers. Poultry Science 91: 376-382. 
60. Resanovic RM, Nesic KD, Nesic VD, Palic TD, Jacevic VM (2009) Mycotoxins in poultry production. Zbornik Matice srpske za prirodne nauke / Proc Nat Sci, Matica Srpska Novi Sad 116: 7-14.

61. Anyanwu EC, Campbell AW, Ehiri JE (2004) Mycotoxins and antifungal drug interactions: implications in the treatment of illnesses due to indoor chronic toxigenic mold exposures. Scientific World Journal 4: 167-177.

62. Andretta I, Kipper M, Lehnen CR, Hauschild L, Vale MM, et al. (2011) Meta-analytical study of productive and nutritional interactions of mycotoxins in broilers. Poultry Science 90: 19341940.

63. Zain ME (2011) Impact of mycotoxins on humans and animals. Journal of Saudi Chemical Society 15: 129-144.

64. Chen X, Grenier B, Applegate TJ (2013) Aflatoxins in Poultry. Department of Animal Sciences, Purdue University.

65. Ostry V, Toman J, Grosse Y (2017) Mycotoxins as human carcinogens- the IARC Monograghs classification. Mycotoxin Research 33: 65-73.

66. O'Brien E, Dietrich DR (2004) Mycotoxins affecting the kidney. In: Hook JB, Raton B, editors. Toxicology of Kidney: CRC Pr. pp. 895-936.

67. Wu H-C, Wang Q, Yang H, Ahsan H, Tsai W-Y, et al. (2009) Aflatoxin B1 exposure, hepatitis B virus infection, and hepatocellular carcinoma in Taiwan. Cancer Epidemiol Biomarkers Prev 18: 846-853.

68. Wang L-Y, Hatch M, Chen C-J, Levin B, You S-L, et al. (1996) Aflatoxin exposure and risk of hepatocellular carcinoma in Taiwan. Int J Cancer 67: 620-625.

69. Dhesy-Thind S (2018) Human papillomavirus status and esophageal adenocarcinoma worth a closer look? JAMA Netw Open 1.

70. Park S-H, Kim D, Kim J, Moon Y (2015) Effects of mycotoxins on mucosal microbial infection and related pathogenesis. Toxins 7: 4484-4502.

71. Kumar A, Jindal N, Shukla CL, Pal Y, Ledoux DR, et al. (2003) Effect of ochratoxin A on Escherichia coli-challenged broiler chicks. Avian Diseases 47: 415-424.

72. Parkin DM, Bray F, Ferlay J, Jemal A (2014) Cancer in Africa 2012. Cancer Epidemiol Biomarkers Prev 23: 953-966.

73. Tettey M, Edwin F, Aniteye E, Sereboe L, Tamatey M, et al. (2012) The changing epidemiology of esophageal cancer in sub-Saharan Africa - the case of Ghana. Pan African Medical Journal 13: 6.

74. MoH (2017) National Cancer Control Strategy 2017 - 2022. Nairobi, Kenya: Ministry of Health, Government of Kenya, June 2017. pp. 80 pages.

75. Dawsey SP, Tonui S, Parker RK, Fitzwater JW, Dawsey SM, et al. (2010) Esophageal cancer in young people: a case series of 109 cases and review of the Literature. PLOS ONE 5. 
76. Odera JO, Odera E, Githang'a J, Walong EO, Li F, et al. (2017) Esophageal cancer in Kenya. The American Journal of Digestive Diseases 4: 23-33.

77. Valavanidis A (2017) Environmental carcinogenic substances, exposure and risk assessment for carcinogenic potential. Classifications and regulations by international and national institutions. In: Valavanidis A, editor. Scientific Reviews. Athens, Greece: Department of Chemistry, National and Kapodistrian University of Athens, University Campus Zografou.

78. Littlefield NA, Farmer JH, Gaylor DW, Sheldon WG (1980) Effects of dose and time in a longtime, low-dose carcinogenic study. Journal of Environmental Pathology and Toxicology 3 17-34.

79. Cameron HM, Wariwick GP (1977) Primary cancer of the liver in Kenyan children. Br J Cancer 36: 793-803.

80. Lombar MJ (2014) Mycotoxin exposure and infant and young child growth in Africa: What do we know? Ann Nutr Metab 64: 42-52.

81. Boffetta P, Hashibe M (2006) Alcohol and cancer. Lancet Oncol 7: 149-156.

82. IARC. A review of human carcinogens IARC Monographs on the evaluation of carcinogenic risks to humans. In: Humans IWGotEoCRt, editor; 201224 February-3 March 2009; Lyon, France. World Health Organization

International Agency for Research on Cancer. pp. 485

83. Macharia LW, Mureithi M, W., Anzala O (2019) Cancer in Kenya: types and infectionattributable. Data from two hospitals. . AAS Open Research 1: 125.

84. Ojuka D, Dindi K, Awori M (2017) Prevalence of esophageal adenocarcinoma. Ann Afr Surg 14: 82-85.

85. Korir A, Okerosi N, Ronoh V, Mutuma G, Parkin M (2015) Incidence of cancer in Nairobi, Kenya (2004-2008). International Journal of Cancer 137: 2053-2059.

86. Patel K, Wakhisi J, Mining S, Mwangi A, Patel R (2013) Esophageal cancer, the topmost cancer at MTRH in the Rift Valley, Kenya, and its potential risk factors. Oncology 2013: 9 pages.

87. Wagner C (2015) Critical Practicalities in Sampling for Mycotoxins in Feed. Journal of AOAC Internatlonal 98: 301-308.

88. Codex (2018) General standard for contaminants and toxins in food and feed. CXS 193: 1995. Adopted in 1995 Revised in 1997, 2006, 2008, 2009 Amended in 2010, 2012, 2013, 2014, 2015, 2016, 2017, 2018. Codex Alimentarius (International Food Standards): FAO/ WHO. pp. 65.

89. Matumba L, Poucke CV, Ediage EN, Saeger SD (2017) Keeping mycotoxins away from food. Does existence of regulations have any impact in Africa? . Crit Rev Food Sci Nutr 57 15841592.

90. Cardwell KF (1999) Mycotoxin Contamination in Foods- Anti-Nutritional Factors. Improving Human Nutrition Through Agriculture: The Role of International Agricultural Research , a 


\section{Supporting information}

656 S1 Dataset. Dietary mycotoxin hazards (Excel doc).

657

\section{Author Contributions}

659 Conceptualization: James Kibugu, Delia Grace, Lindahl Johanna

660 Data Curation: James Kibugu

661 Formal Analysis: James Kibugu, Richard Kurgat

662 Funding Acquisition: James Kibugu, Delia Grace, Lindahl Johanna, Leonard Munga

663 Investigation: James Kibugu, Lindahl Johanna, David Mburu, Leonard Munga

664 Methodology: James Kibugu, Delia Grace, Lindahl Johanna

665 Project Administration: James Kibugu

666 Resources: James Kibugu, Fransisca Lusweti, Bernard Mukasa

667 Software: James Kibugu

668 Supervision: James Kibugu, Delia Grace, Lindahl Johanna

669 Validation: James Kibugu, Delia Grace, Lindahl Johanna

670 Visualisation: James Kibugu

671 Writing-Original Draft Preparation: James Kibugu

672 Writing-Review \& Editing: James Kibugu, Delia Grace, Lindahl Johanna, Leonard Munga, 